\title{
Elderly immunocompetent man presenting with disseminated cutaneous herpes zoster
}

\author{
Uddalak Chakraborty, ${ }_{1}^{1}$ Atanu Chandra, ${ }^{1}$ Abheek Sil, ${ }^{2}$ Surajit Kumar Biswas ${ }^{2}$
}

'Internal Medicine, RG Kar Medical College and Hospital, Kolkata, West Bengal, India ${ }^{2}$ Dermatology, Venereology, Leprosy, RG Kar Medical College and Hospital, Kolkata, West Bengal, India

\section{Correspondence to} Dr Atanu Chandra; chandraatanu123@gmail.com

Accepted 15 July 2020

\section{DESCRIPTION}

A 60-year-old man presented to us with a history of vesicular eruptions involving his right upper limb associated with a sharp lancinating pain over the affected area for 6 days. His wife noticed new vesicular eruptions appearing over the entire trunk, back and face of the patient over the next 2 days. He did not report any fever, cough, respiratory distress, headache, neck stiffness or pain in the abdomen nor could he recall any history of chicken pox in the past, or any such recent contact. He did not suffer from any chronic ailments nor had he been on systemic steroids or any immunosuppressive medications in the recent past.

On admission, the patient was afebrile with stable vital signs. Cutaneous examination revealed multiple grouped vesicles on an erythematous base with focal crusting arranged over the radial aspect of right palm and extensor surface of right forearm, configured along the C6-C7 dermatomal segments (Panel A and B). Scattered vesicles with erosions and crusts were seen diffusely distributed over the face, trunk and back (Panel C and D) (figure 1). There was no evidence of any lymphadenopathy or organomegaly. Ophthalmological evaluation did not reveal any corneal involvement. Rest of the systemic examinations were unremarkable.

Complete blood count, liver and renal function tests and screening for diabetes were unremarkable. Serology for HIV 1 and 2, viral hepatitis markers and venereal disease research laboratory tests were negative. Serum protein electrophoresis was within normal limits. Examination of vesicle fluid from a truncal lesion demonstrated multinucleate giant cells on Tzanck smear whereas PCR was positive

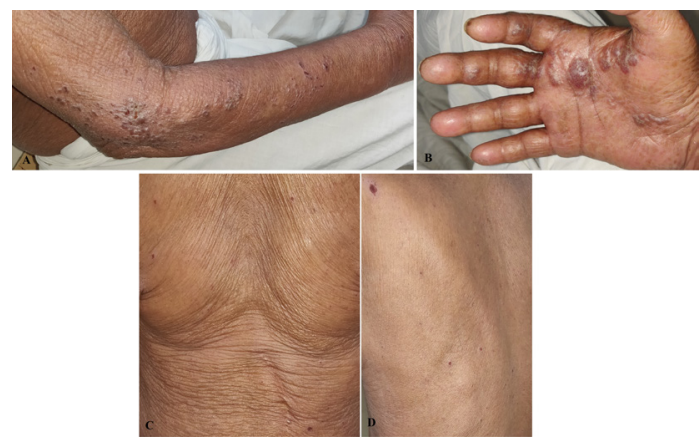

Figure 1 Elderly man with disseminated cutaneous herpes zoster showing grouped vesicles on an erythematous base with focal crusting along $\mathrm{C6}-\mathrm{C7}$ dermatome of right upper arm (Panel $A$ and $B$ ) and diffusely distributed vesicles and erosions involving the back and trunk (Panel C and D). for varicella zoster virus (VZV) and negative for herpes simplex virus. Imaging of chest, abdomen and pelvis revealed no abnormality.

The patient was immediately started on intravenous acyclovir ( $800 \mathrm{mg}$ every 8 hours) along with analgesics. No further eruptions were noted from the next day. He was continued on intravenous acyclovir for a week and subsequently discharged on oral acyclovir ( $800 \mathrm{mg}$ five times a day) for the next 7 days. He remained symptom-free after 6 months of follow-up.

Disseminated cutaneous herpes zoster (DCHZ) is defined by the presence of more than 20 vesicles beyond the primary or adjacent dermatomes. ${ }^{1} \mathrm{VZV}$ usually remains dormant in the sensory ganglion after primary infection; however, recollection of preceding varicella infection may not be elicited due to infection during early childhood, subclinical manifestation or misdiagnosis as some other viral exanthem. ${ }^{2}$ VZV-specific cell-mediated immunity is very important to prevent reactivation of the primary infection. ${ }^{3}$ Thus, this complication of zoster has been predominantly reported in individuals with underlying immunosuppression (especially in T-cell deficiency) like HIV, cancer, chemotherapy or immunosuppressive therapy, bone marrow transplant recipients and immunological disorders;

\section{Patient's perspective}

I am happy with the treatment I received here. I was thoroughly screened by my team of doctors and they made sure that no stones were unturned, I was having something probably less common.

\section{Learning points}

Disseminated cutaneous herpes zoster (DCHZ) is a potentially serious infection that can present, although rarely, in an immunocompetent individual. Underlying immunosuppression should always be ruled out in disseminated zoster disease.

- Patients with DCHZ should be screened for associated visceral organ involvement, especially the lungs, liver and brain. However, cutaneous dissemination in immunocompetent individuals have been found to be associated with low morbidity and mortality due to sufficient VZV cell-mediated immunity.

- Intravenous acyclovir is the treatment of choice for DCHZ. 
severe cutaneous and visceral disseminated disease have been reported in such patients. ${ }^{1}$ Healthy immunocompetent individuals afflicted with this condition have been rarely reported in the literature. ${ }^{4} \mathrm{VZV}$-specific cellular immunity which gradually declines with advancing age may have contributed to the dissemination, as seen in our case. ${ }^{5}$

Patients with DCHZ are also at an increased risk of other visceral organ involvement, especially the lungs, liver and brain. However, mortality and morbidity risks are relatively low for immunocompetent patients with DCHZ. Prompt diagnosis and management with intravenous acyclovir is advocated in such patients.

Contributors AC prepared the manuscript and collected all relevant data and investigations and was involved directly in patient care. UC was directly involved in patient care, edited the manuscript and assisted in collecting all laboratory investigations. AS helped with the images, supervised the entire procedure of preparing the manuscript. SKB supervised the treatment and gave expert opinion regarding the case. He also supervised the entire attempt to report the case.
Funding The authors have not declared a specific grant for this research from any funding agency in the public, commercial or not-for-profit sectors.

Competing interests None declared.

Patient consent for publication Obtained.

Provenance and peer review Not commissioned; externally peer reviewed.

\section{REFERENCES}

1 Brown TJ, McCrary M, Tyring SK. Varicella-Zoster virus (herpes 3). J Am Acad Dermatol 2002:47:972-97.

2 Jerant AF, DeGaetano JS, Epperly TD, et al. Varicella susceptibility and vaccination strategies in young adults. J Am Board Fam Pract 1998;11:296-306.

3 Arvin A. Aging, immunity, and the varicella-zoster virus. N Eng/ I Med 2005;352:2266-7.

4 Gupta S, Jain A, Gardiner C, et al. A rare case of disseminated cutaneous zoster in an immunocompetent patient. BMC Fam Pract 2005;6:50.

5 Levin MJ, Smith JG, Kaufhold RM, et al. Decline in varicella-zoster virus (VZV)-specific cell-mediated immunity with increasing age and boosting with a high-dose VZV vaccine. J Infect Dis 2003;188:1336-44.

Copyright 2020 BMJ Publishing Group. All rights reserved. For permission to reuse any of this content visit

https://www.bmj.com/company/products-services/rights-and-licensing/permissions/

BMJ Case Report Fellows may re-use this article for personal use and teaching without any further permission.

Become a Fellow of BMJ Case Reports today and you can:

- Submit as many cases as you like

- Enjoy fast sympathetic peer review and rapid publication of accepted articles

- Access all the published articles

Re-use any of the published material for personal use and teaching without further permission

Customer Service

If you have any further queries about your subscription, please contact our customer services team on +44 (0) 2071111105 or via email at support@bmj.com.

Visit casereports.bmj.com for more articles like this and to become a Fellow 